\title{
URGENSI BUDAYA ORGANISASI BAGI KEMAJUAN \\ LEMBAGA PENDIDIKAN ISLAM
}

\author{
DEDIK \\ Lecturer in FITK at UIN North Sumatera, Medan \\ Jalan Williem Iskandar Pasar V, Medan Estate, Medan, Sumatera Utara 20371 \\ E-mail: dikdedik@yahoo.com
}

\begin{abstract}
Cultural organizations have a strategic role to encourage and enhance the effectiveness of the organization's performance, both in the short and long term. Organizational culture acts as a social glue that binds fellow members of the organization together in a common vision and purpose.
\end{abstract}

Keywords: Cultural Organizations, Islamic Educational Institution.

\begin{abstract}
Abstrak
Budaya organisasi memiliki peran strategis untuk mendorong dan meningkatkan efektifitas kinerja organisasi, baik dalam jangka pendek maupun dalam jangka panjang. Budaya organisasi bertindak sebagai perekat sosial yang mengikat sesama anggota organisasi bersama-sama dalam visi dan tujuan bersama.
\end{abstract}

Kata Kunci: Budaya Organisasi, Lembaga Pendidikan Islam.

\section{PENDAHULUAN}

Pendidikan adalah suatu kegiatan yang dipercaya mampu meningkatkan kompetensi manusia, baik pengetahuan, sikap dan perilaku. Dengan kegiatan pendidikan diharapkan sebagai pintu gerbang pertama seseorang mendapatkan pengetahuan dalam dirinya. Oleh karenanya perhatian masyarakat terhadap pentingnya pendidikan menjadi suatu kepastian sekaligus harapan.

Sejatinya, lembaga pendidikan sebagai satu wadah yang secara formal melaksanakan kegiatan pendidikan yang teratur, terencana dan terprogram menjadi tujuan bagi setiap pemakai (user). Bagi orang tua, mereka adalah masyarakat yang berkepentingan menitipkan anak-anaknya belajar di lembaga tersebut. Selanjutnya bagi perusahaan, mereka adalah kelompok yang berkepentingan untuk menggunakan para lulusan lembaga pendidikan agar mampu menjadi karyawan yang tangguh di perusahaanya kelak. Harapan inilah yang dinanti oleh setiap masyarakat terhadap lembaga pendidikan. Namun tidak semua lembaga pendidikan mampu mengemban amanah ini. Hal ini dikarenakan beberapa faktor yang ikut menjadi penentu terhadap pelaksanaan kegiatan tersebut. Faktor-faktor tersebut bisa berasal dari intern organisasi atau juga bisa berasal dari ekstern organisasi. Faktor yang berasal dari intern organisasi bentuknya banyak di antaranya adalah budaya organisasi.

Suatu organisasi dibentuk untuk mencapai suatu tujuan tertentu. Oleh karena itu, 
keberhasilan suatu organisasi ditunjukkan oleh kemampuannya mencapai tujuan yang telah ditetapkan sebelumnya. Keberhasilan organisasi dalam mencapai tujuan sangat ditentukan oleh kinerja organisasi yang sangat dipengaruhi oleh faktor eksternal maupun internal organisasi ${ }^{1}$.

Faktor eksternal adalah segala sesuatu yang berada di luar organisasi, namun mempunyai pengaruh besar terhadap organisasi dan budayanya. Kecenderungan global yang semakin kompetitif berpengaruh kuat pada budaya organisasi. Apabila tidak mampu merespons pengaruh global akan berdampak pada kesulitan organisasi. Demikian pula kecenderungan pertumbuhan demografi, sosial, ekonomi, dan politik di dalam negeri berpengaruh terhadap kinerja organisasi.

Sebagai faktor internal organisasi selain didukung sumber daya yang diperlukan untuk mewujudkan kinerja organisasi, maka yang sangat besar peranannya adalah budaya organisasi yang dianut segenap sumber daya manusia dalam organisasi.

\section{PENGERTIAN BUDAYA ORGANISASI}

Budaya berasal dari bahasa sansekerta "budhayah" sebagai bentuk jamak dari kata dasar "buddhi" yang artinya akal atau segala sesuatu yang berkaitan dengan akal pikiran, nilai-nilai dan sikap mental. ${ }^{2}$ Selanjutnya J. Verkuyl menulis bahwa kata kebudayaan itu mulai dipakai kira-kira pada tahun 1930 dan dengan cepat merebut tempat yang tetap dalam perbendaharaan bahasa Indonesia. Menurutnya kata kebudayaan itu berasal dari bahasa Sanskerta budaya, yakni bentuk jamak dari budi yang berarti roh atau akal. Perkataan kebudayaan menyatakan : segala sesuatu yang diciptakan oleh budi manusia ${ }^{3}$.

Senada dengan pendapat di atas, P.J. Zoetmulder dalam sebuah bukunya Culture, Oost en West seperti dikutip Faisal Ismail mengatakan bahwa kata kebudayaan itu adalah suatu perkembangan dari kata majemuk "budi-daya" yang artinya daya dari budi atau kekuatan dari akal. Budidaya berarti memberdayakan budi sebagaimana dalam bahasa Inggris dikenal sebagai culture berasal dari kata Latin colere yang semula artinya mengolah atau mengerjakan sesuatu (mengolah tanah pertanian), kemudian berkembang arti culture sebagai segala daya dan usaha manusia untuk mengubah alam. Istilah culture (Inggeris) telah diindonesiakan menjadi kultur yang sama pengertiannya dengan kebudayaan atau bila

${ }^{1}$ Wibowo, Budaya Organisasi:Sebuah Kebutuhan untuk Meningkatkan Kinerja Jangka Panjang, Cet. Ke-1 ( Jakarta: Rajagrafindo Persada, 2010), hlm. 1

${ }^{2}$ Keputusan Menteri Pendayagunaan Aparatur Negara RI Nomor 25/KEP/M.PAN/04/2002 tentang: Pedoman Pengembangan Budaya Kerja Aparatur Negara (Jakarta: 2002). Hal senada juga pernah diungkapkan oleh Koentjaraningrat dalam bukunya berjudul Kebudayaan, Mentalitet dan Pembangunan, Cet. Ke-1 (Jakarta: Gramedia, 1976), hlm. 137; Diungkapkan bahwa kata kebudayaan itu adalah berasal dari bahasa Sanskerta budhayah, yang merupakan bentuk jamak dari buddhi yang berarti budi dan akal. Dengan demikian kebudayaan dapat diartikan "hal-hal yang bersangkutan dengan budi dan akal.

${ }^{3}$ J.Verkuyl, Etika Kristen dan Kebudayaan, terj. Soegiarto. Cet. Ke-2 (Jakarta: Badan Penerbit Kristen 1966),

h. 13 
dituliskan secara singkat menjadi budaya. Istilah tersebut daam bahasa Arab disebut Tsaqafah ${ }^{4}$.

Selanjutnya Veithzal Rivai mengatakan bahwa organisasi adalah wadah yang memungkinkan masyarakat dapat meraih hasil yang sebelumnya tidak dapat dicapai individu secara sendiri-sendiri. Organisasi merupakan suatu unit terkordinasi yang terdiri setidaknya dua orang, berfungsi mencapai satu sasaran tertentu atau serangkaian sasaran ${ }^{5}$.

Adapun penerapan budaya tersebut di dalam organisasi menjadi budaya organisasi. Di antara para pakar memberikan pengertian tentang budaya organisasi dengan cara sangat beragam, karena masing-masing memberikan tekanan pada sudut pandang masing-masing. Hal seperti itu adalah wajar, seperti memandang sebuah benda dari sudut yang berbeda, maka masing-masing akan mendeskripsikan apa yang terlihat menurut pandangannya ${ }^{6}$.

Edgar H Schein mengemukakan: An Organization's culture is a pattern of basic assumptions invented, discovered or develop by a given group as it learns to cope with its problems of external adaptation and internal integration that has worked well enough to be considered valid and to be taught to new members as the correct way to perceive, think and feel in relation to these problems. Dikatakan bahwa budaya organisasi ialah seperangkat asumsi dasar atau sistem keyakinan, nilai-nilai dan norma yang dikembangkan dalam organisasi yang dijadikan pedoman tingkah laku bagi anggota-anggotanya untuk mengatasi masalah adaptasi eksternal dan integrasi internal7.

Hal senada juga dikatakan Keith Davis dan John Newstrom bahwa: "organizational culture is the set of assumptions, beliefs, values, and norms that is shared among its members" Dikatakan bahwa budaya organisasi adalah sejumlah asumsi, kepercayaan, nilai dan norma yang berlaku diantara para anggota ${ }^{8}$.

Adapun Jerald Greenberg dan Robert A. Baron menyatakan bahwa budaya organisasi sebagai kerangka kerja kognitif yang terdiri dari sikap, nilai-nilai, norma perilaku dan harapan yang diterima bersama oleh anggota organisasi. Akar setiap budaya organisasi adalah serangkaian karakteristik inti yang dihargai secara kolektif oleh anggota organisasi ${ }^{9}$.

Budaya organisasi menurut Stephen P. Robbins ialah persepsi umum yang dipegang anggota organisasi, suatu sistem keberartian bersama. Budaya organisasi berkepentingan

${ }^{4}$ Faisal Ismail, Paradigma Kebudayaan Islam: Studi Kritis dan Refleksi Historis. Cet. Ke-2 (Yogyakarta: Titian Ilahi Press, 1997), hlm. 24

${ }^{5}$ Veithzal Rivai \& Deddy Mulyadi, Kepemimpinan dan Perilaku Organisasi ( Jakarta: Rajagrafindo Persada, 2009, Ed.III), hlm. 169-170

${ }^{6}$ Wibowo, Budaya Organisasi..., 2010, hlm. 16

${ }^{7}$ Edgar H Schein, An Organizational Culture and Leadership, hlm.21

${ }^{8}$ Davis dan John Newstrom, Human Behavior at Work: Organizational Behavior ( New York: Mc Graw Hill International, 1989), hlm.60

${ }^{9}$ Jerald Greenberg dan Robert A. Baron, Behavior in Organizations (New Jersey: Prentice-Hall, 2003), hlm. 
dengan bagaimana pekerja merasakan karakteristik suatu budaya organisasi, tidak dengan apakah seperti mereka atau tidak $^{10}$.

Sementara itu, menurut James L. Gibson, John M. Ivancevich, dan James H. Donnelly, Jr memberikan pengertian budaya organisasi sebagai apa yang dirasakan pekerja dan bagaimana persepsi ini menciptakan pola keyakinan, nilai-nilai dan harapan ${ }^{11}$.

Adapun menurut Robert Kreitner dan Angelo Kinicki, budaya organisasi adalah nilai-nilai dan keyakinan bersama yang mendasari indentitas perusahaan. Defenisi Kreitner dan Kinicki ini menunjukkan tiga karakteristik penting budaya organisasi, yaitu: (1) budaya organisasi diteruskan kepada pekerja baru melalui proses sosialisasi, (2) budaya organisasi memengaruhi perilaku kita dipekerjaan, dan (3) budaya organisasi bekerja pada dua tingkatan yang berbeda ${ }^{12}$.

Menurut Barry Phegan, budaya organisasi adalah tentang bagaimana orang merasa tentang melakukan pekerjaan baik dan apa yang membuat peralatan dan orang bekerja bersama dalam harmoni. Budaya organisasi merupakan pola yang rumit tentang bagaimana orang melakukan sesuatu, apa yang mereka yakini, apa yang dihargai dan dihukum. Adalah tentang bagaimana dan mengapa orang mengambil pekerjaan yang berbeda dalam perusahaan $^{13}$.

Adapun Michael Zwell menyatakan budaya korporasi sebagai cara hidup suatu organisasi yang diberikan melalui generasi penerus pekerja. Budaya termasuk siapa kita, apa yang kita yakini, apa yang kita lakukan, dan bagaimana melakukannya ${ }^{14}$.

Victor S.L Tan mendefenisikan budaya korporasi sebagai cara orang melakukan sesuatu dalam organisasi. Budaya organisasi merupakan serangkaian norma terdiri dari keyakinan, sikap, nilai-nilai inti dan pola perilaku, dibagikan oleh orang dalam suatu organisasi. Keyakinan bersama, nilai-nilai inti dan pola perilaku memengaruhi kinerja dalam organisasi. Belief atau keyakinan adalah asumsi atau persepsi tentang sesuatu, orang dan organisasi secara keseluruhan, diterima sebagai sesuatu yang benar dan layak. Core values adalah nilai dominan atau inti, yang diterima di seluruh organisasi. Behavior pattern atau pola perilaku adalah cara orang bertindak satu sama lain ${ }^{15}$.

Jerome Want menyatakan bahwa budaya organisasi adalah sebuah sistem keyakinan kolektif yang dimiliki orang dalam organisasi tentang kemampuan mereka bersaing di pasar, dan bagaimana mereka bertindak dalam sistem keyakinan tersebut untuk memberi

${ }^{10}$ Stephen P. Robbins, Organizational Behavior ( New Jersey: Prentice Hall International, Inc., 2003), hlm.

${ }^{11}$ James L. Gibson, dkk, Jr, Organizations (Boston: McGraw-Hill Higher Education,2000), hlm. 30

${ }^{12}$ Robert Kreitner dan Angelo Kinicki, Organizational Behavior ( New York: McGraw-Hill Higher Education, 2001) hlm.68

hlm. 1

${ }^{13}$ Barry Phegan, Developing Your Company Culture ( Berkeley:Contex Press, Meridian Group, Inc., 2000),

${ }^{14}$ Michael Zwell, Creating a Culture of Competence (New York: John Wiley \& Sons, Inc.,2000), hlm. 9

${ }^{15}$ Victor S.L Tan, Changing Your Corporate Culture ( Singapore: Times Books International, 2002), hlm.18 
nilai tambah produk dan jasa di pasar (pelanggan) sebagai imbalan atas penghargaan finansial. Budaya organisasi diungkapkan melalui sikap, sistem keyakinan, impian, perilaku, nilai-nilai, tata cara dari perusahaan, dan terutama melalui tindakan serta kinerja pekerja dan manajemen ${ }^{16}$.

Di antara pendapat para pakar tersebut tampak bahwa ada di antaranya memberikan pengertian yang lebih filosofis, namun ada pula yang lebih bersifat operasional.

Dari pengertian tersebut, dapat disimpulkan bahwa budaya organisasi adalah filosofi dasar organisasi yang memuat keyakinan, norma-norma, dan nilai-nilai bersama yang menjadi karakteristik inti tentang bagaimana cara melakukan sesuatu dalam organisasi. Keyakinan, norma-norma, dan nilai-nilai tersebut menjadi pegangan semua sumber daya manusia dalam organisasi dalam melaksanakan kinerjanya.

\section{PEMBENTUKAN BUDAYA ORGANISASI}

Pada dasarnya untuk membentuk budaya organisasi yang kuat memerlukan waktu yang cukup lama dan bertahap. Di dalam perjalanannya sebuah organisasi mengalami pasang surut, dan menerapkan budaya organisasi yang berbeda dari satu waktu ke waktu yang lain. Budaya bisa dilihat sebagai suatu hal yang mengelilingi kehidupan orang banyak dari hari ke hari, dapat direkayasa dan dibentuk. Jika budaya dikecilkan cakupannya ke tingkat organisasi atau bahkan kekelompok yang lebih kecil, akan dapat terlihat bagaimana budaya terbentuk, ditanamkan, berkembang, dan akhirnya, direkayasa, diatur dan diubah .

Menurut Wibowo, proses pembentukan budaya organisasi pada umumnya dimulai dari sumbernya, yaitu filosofi pendiri. Pendiri organisasi menanamkan budaya organisasi seperti apa yang seharusnya dilaksanakan dalam organisasi. Filosofi dasar ini sangat memengaruhi kriteria yang diperlukan dalam merekrut dan menseleksi sumber daya manusia. Dengan sumber daya manusia dimaksudkan semua tenaga kerja yang terdapat dalam organisasi pada berbagai tingkat kedudukannya, baik pada pimpinan tingkat atas, menengah, bawah maupun pekerja. Selanjutnya manajemen puncak akan menetapkan iklim perilaku, seperti apa yang dapat diterima dan apa yang tidak diterima dalam organisasi ${ }^{17}$.

Untuk itu, manajemen puncak perlu melakukan sosialisasi tentang budaya organisasi yang ditetapkan kepada seluruh sumber daya manusia. Bentuk sosialisasi akan dilakukan tergantung pada tingkat keberhasilan yang dicapai dalam memadukan antara nilai-nilai yang dimiliki sumber daya manusia baru ke dalam mereka yang sudah ada di dalam organisasi ${ }^{18}$.

Stephen P. Robbins meperhatikan bahwa proses pembentukan budaya organisasi dilakukan melalui tiga cara, yaitu:

${ }^{16} J$ rome Want, Corporate Culture ( New York: St. Martin's Press, 2007), hlm.42

${ }^{17}$ Wibowo, Budaya Organisasi..., 2010,, hlm. 67

${ }^{18}$ Ibid. 
1. Pendiri hanya merekrut dan menjaga pekerja yang berpikir dan merasa dengan cara yang sama untuk melakukannya.

2. Mengindoktrinasi dan mensosialisasi pekerja dalam cara berpikir dan merasakan sesuatu.

3. Perilaku pendiri sendiri bertindak sebagai model peran yang mendorong pekerja mengindentifikasi dengan mereka dan kemudian menginternalisasi keyakinan, nilai dan asumsi. Ketika organisasi berhasil, visi pendiri menjadi terlihat menjadi determinan utama keberhasilan ${ }^{19}$.

Dapat dipahami bahwa pendiri sekaligus bertindak sebagai pemimpin pada tahap awal organisasi menginginkan bawahannya dapat menjalankan apa yang menjadi tujuannya dengan berdasar pada filosofi dan pola pikir yang dipandangnya benar berdasarkan pengalamannya.

Berikut ini adalah gambar proses terbentuknya budaya organisasi menurut Stephen P. Robbins sebagai berikut :

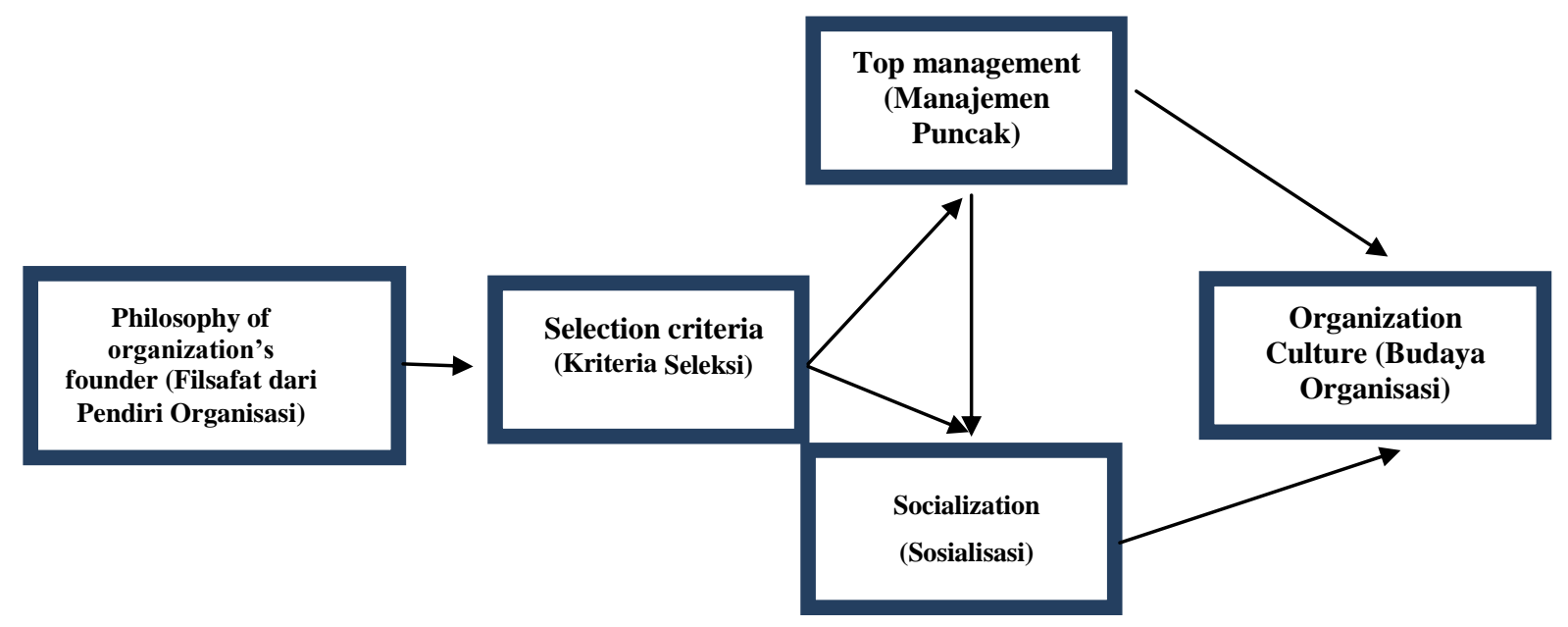

\section{Gambar 1. Proses Terbentuknya Budaya Organisasi}

\section{Sumber: Stephen P.Robbins ${ }^{20}$}

Gambar 1. menjelaskan bahwa budaya asli diturunkan dari filsafat pendirinya, kemudian budaya ini sangatlah mempengaruhi kriteria yang dipergunakan dalam mempekerjakan karyawan. Tindakan dari manajemen puncak menentukan iklim umum dari perilaku yang dapat diterima baik dan yang tidak. Tingkat kesuksesan dalam mensosialisasikan budaya lembaga (perusahaan) tergantung pada kecocokan nilai-nilai karyawan baru dengan nilai-nilai organisasi dalam proses seleksi maupun pada preferensi manajemen puncak akan metode-metode sosialisasi.

Adapun proses sosialisasi menurut Stephen P. Robbins perlu dilakukan dengan urutan sebagai berikut :

${ }^{19}$ Stephen P. Robbins, Organizational Behavior, 2003, hlm. 531

${ }^{20}$ Ibid., hlm.535 
1. The prearrival stage, merupakan periode pembelajaran dalam proses sosialisasi yang terjadi sebelum pekerja baru bergabung dalam organisasi.

2. The encounter stage, suatu tahapan sosialisasi di mana pekerja baru melihat apa yang diinginkan organisasi di mana pekerja baru dapat melihat apa yang dinginkan organisasi dan menghadapi kemungkinan bahwa antara harapan dan realitas mungkin berbeda.

3. The metamorphosis stage, suatu tahapan proses sosialisasi di mana pekerja baru berubah dan menyesuaikan diri pada pekerjaan, kelompok kerja, dan organisasi ${ }^{21}$.

Selanjutnya Anwar Prabu Mangkunegara mengatakan bahwa fungsi budaya organisasi dalam program pencapaian efektivitas organisasi dapat dilihat melalui tabel berikut ini:

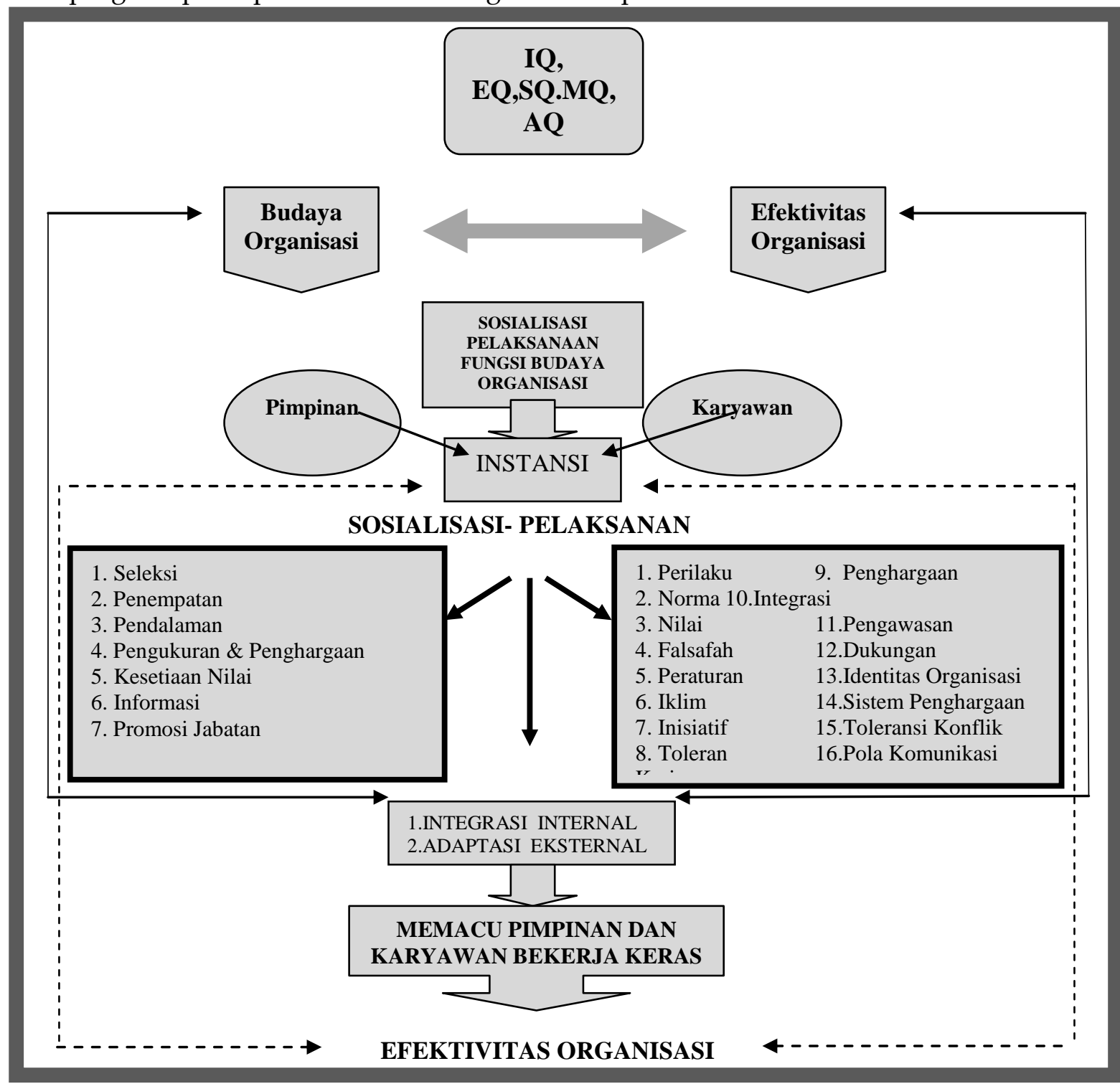

Gambar 2. Budaya Organisasi dan Pencapaian Efektivitas Organisasi²2.

${ }^{21}$ Ibid, hlm. 533

22 Anwar Prabu Mangkunegara, Perilaku dan Budaya Organisasi (Bandung: Refika Aditama, 2005), hlm. 
Pendapat para pakar tentang fungsi budaya organisasi di atas menunjukkan beberapa kesamaan, sedangkan beberapa perbedaan yang ada bersifat saling melengkapi. Dengan demikian dapat disimpulkan bahwa fungsi budaya organisasi adalah: 1) menunjukkan identitas, 2) menunjukkan batasan peran yang jelas, 3) menunjukkan komitmen kolektif, 4) membangun stabilitas sistem sosial, 5) membangun pikiran sehat dan masuk akal dan 6) memperjelas standar perilaku.

Tahapan yang penting dalam proses pembentukan budaya adalah dalam proses sosialisasi kepada segenap sumber daya manusia dalam organisasi. Sosialisasi merupakan suatu proses menyesuaikan pekerja pada budaya organisasi.

\section{BUDAYA ORGANISASI DALAM PERSPEKTIF ISLAMI}

Kajian ini diawali dengan merujuk ayat-ayat Allah SWT yang berkaitan dengan keorganisasian. Di antaranya ialah firman Allah Swt dalam Suroh Al-Baqarah ayat 43 yaitu :

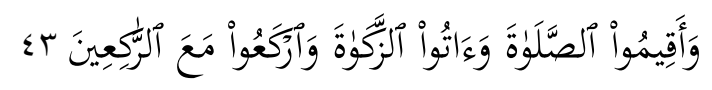

Artinya:Dan Dirikanlah shalat, tunaikanlah zakat dan ruku'lah beserta orang-orang yang ruku ( yang dimaksud ialah: shalat berjama'ah )23.

Selanjutnya firman Allah Swt dalam Suroh An-Nisaa' ayat 71 yaitu :

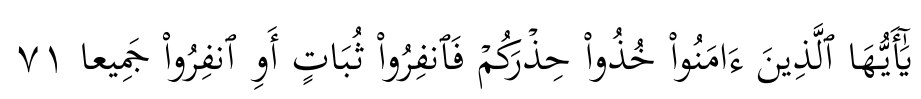

Artinya: Hai orang-orang yang beriman, bersiap siagalah kamu, dan majulah (ke medan pertempuran) berkelompok-kelompok, atau majulah bersama-sama ${ }^{24}$.

Selanjutnya firman Allah Swt dalam Suroh Ash-Shaffat ayat 1 yaitu :

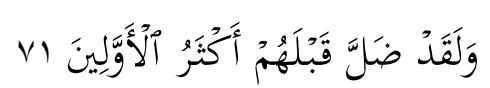

Artinya: Demi (rombongan) yang ber shaf-shaf dengan sebenar-benarnya ${ }^{25}$.

Selanjutnya firman Allah Swt dalam Suroh Al-Hujurat ayat 13 yaitu :

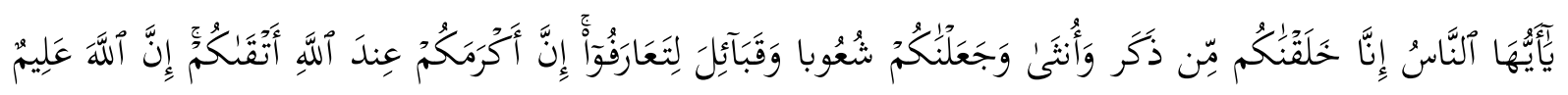

Artinya: Hai manusia, Sesungguhnya kami menciptakan kamu dari seorang laki-laki dan seorang perempuan dan menjadikan kamu berbangsa - bangsa dan bersuku-suku supaya kamu saling kenal-mengenal. Sesungguhnya orang yang paling mulia diantara kamu disisi Allah ialah orang yang paling taqwa di antara kamu. Sesungguhnya Allah Maha mengetahui lagi Maha Mengenal ${ }^{26}$.

\footnotetext{
${ }^{23}$ Q.S al-Baqarah/2:43

${ }^{24}$ Q.S an-Nisaa'/4:71

${ }^{25}$ Q.S Ash-Shaffat/37:1

${ }^{26}$ Q.S al-Hujurat/49:13
} 
Beberapa ayat di atas, menunjukan pentingnya kegiatan bersama dilakukan secara bersama-sama untuk mempercepat terlaksananya sebuah tujuan yang diinginkan.

Budaya organisasi dalam kajian Islam dapat ditelusuri dari beberapa penuturan para pakar kajian Islam berikut ini di antaranya adalah Faisal Ismail. Menurut beliau antara budaya dan Islam dua keadaan yang saling tidak mencakup. Artinya Islam bukan merupakan bagian kebudayaan dan sebaliknya kebudayaan bukan merupakan bagian dari Islam; keduanya berdiri sendiri ${ }^{27}$. Menurutnya budaya berasal dari daya cipta dan karsa manusia, sedangkan Islam adalah wahyu. Berikut ini petikan pernyataanya:

Begitu pula berhubung agama Islam dan kebudayaan Islam itu berdiri sendiri (tentu saja ada saling paut dan saling kait yang erat antara keduanya), maka keduanya dapat dibedakan dengan jelas dan tegas. Shalat misalnya adalah unsur (ajaran) agama, selain berfungsi untuk melestarikan hubungan manusia dengan Tuhan, juga dapat melestarikan hubungan manusia dengan manusia, dan juga menjadi pendorong dan penggerak bagi terciptanya kebudayaan. Untuk tempat shalat, orang membangun mesjid dengan gaya arsitektur yang megah dan indah, masjid itulah kebudayaan. Seluruh segi ajaran Islam menjadi tenaga penggerak bagi penciptaan budaya ${ }^{28}$.

Berangkat dari paparan itu, terdapat hubungan yang erat antara budaya dan Islam. Hubungan erat itu adalah bahwa Islam merupakan dasar, asas, pengendali, pemberi arah dan sekaligus merupakan sumber nilai budaya dalam pengembangan dan perkembangan kultural. Agama Islamlah menjadi pengawal, pembimbing dan pelestari seluruh rangsangan dan gerak budaya, sehingga ia menjadi kebudayaan yang bercorak dan beridentitas Islam.

Berdasarkan penuturan di atas, dapat disimpulkan bahwa budaya organisasi dalam perspektif Islami adalah hasil daya, cipta dan karya manusia dalam kelompok organisasi yang disepakati bersama berdasarkan ajaran Islam sesuai dengan Al-Qur'an dan Hadis.

\section{URGENSI BUDAYA ORGANISASI BAGI KEMAJUAN LEMBAGA PENDIDIKAN ISLAM}

Pendidikan Islam di Indonesia telah berlangsung sejak masuknya Islam ke Indonesia. Menurut catatan sejarah Islam masuk ke Indonesia secara damai, berbeda dengan daerahdaerah lain seperti Mesir, Irak dan Parsi dan beberapa daerah lainnya. Peranan para pedagang dan mubaligh sangat besar dalam proses Islamisai di Indonesia. Salah satu jalur proses Islamisasi itu adalah pendidikan.

Pendidikan telah banyak memainkan perananya dalam mencerdaskan kehidupan bangsa. Selain dari itu telah terjadi pula dinamika perkembangan pendidikan Islam di Indonesia. Salah satu yang amat strategis dalam dinamika itu adalah masuknya Pendidikan

\footnotetext{
${ }^{27}$ Faisal Ismail, Paradigma Kebudayaan Islam, hlm. 43

${ }^{28}$ Ibid., h. 44
} 
Islam sebagai sub sistem pendidikan nasional. Ini berarti bahwa pendidikan Islam diakui keberadaanya dalam sistem pendidikan nasional, yang dibagi kepada tiga hal. Pertama pendidikan Islam sebagai lembaga; kedua pendidikan Islam sebagai mata pelajaran; dan ketiga pendidikan Islam sebagai mata pelajaran. ${ }^{29}$

UU No. $2 \mathrm{O}$ tahun 2003 adalah UU Sistem Pendidikan Nasional, yang baru dan menggantikan UUSPN No. 2 Tahun 1989. Dalam Undang-Undang ini, pendidikan dibagi kepada tiga jenis: ${ }^{30}$

1. Pendidikan Formal (SD, SMP, SMA, PT dan setingkatnya).

2. Pendidikan nonformal yang diselenggarakan oleh masyarakat.

3. Pendidikan informal.

Pendidikan madrasah sendiri dikelompokkan kepada pendidikan formal. Pasal 17 dalam UUSPN ini menetapkan bahwa pendidikan dasar berbentuk madrasah/pesantren dasar, madrasah ibtidaiyah dan bentuk lain yang sederajat serta madrasah/pesantren menengah pertama dan madrasah tsanawiyah atau bentuk lain yang sederajat. ${ }^{31}$

Passl 18 menyebutkan: "Pendidikan menengah berbentuk Madrasah/pesantren Menengah Atas, Madrasah Aliyah, Madrasah/pesantren Menengah Kejuruan, dan Madrasah Aliyah Kejuruan atau bentuk lain yang sederajat". ${ }^{32}$

UUSPN tahun 2003 merupakan perkembangan termutakhir pendidikan Islam dalam sistim pendidikan nasional. Dengan diundangkannya UUSPN ini, lembaga-lembaga pendidikan Islam lainnya selain madrasah telah diakui secara sempurna sebagai salah satu lembaga pendidikan nasional. Hal ini seperti yang tercantum dalam pasal 17 dan 18.

Secara otomatis, pesantren sebagai lembaga pendidikan Islam mulai menemukan bentuknya secara bebas di antara lembaga-lembaga pendidikan Islam lainnya. Legalitas pendidikan pesantren telah disamakan dengan legalitas pendidikan lainya, baik dalam sistem kurikulm maupun sistim pembelajarannya.

Pesantren tidak lagi harus mengikuti ujian-ujian persamaan atau menginduk kepada madrasah-madrasah sebagai lembaga yang telah diakui oleh pemerintah. Pesantren telah mendapatkan legalitasnya meskipun tidak mengikuti kurikulum atau program yang disediakan oleh pemerintah.

UUSPN tahun 2003 tetap dianggap sebagai tonggak peristiwa bersejarah dalam perkembangan positif pendidikan Islam dan lembaganya dalam sistim pendidikan nasional.

\footnotetext{
${ }^{29}$ Haidar. P. Daulay, “Kedudukan Pendidikan Islam di Indonesia dalam Undang-Undang No. 20 Tahun 2003 tentang Sistem Pendidikan Nasional," dalam Hasan Asari \& Amroeni Drajat (ed), Antologi Kajian Islam (Bandung: Citapustaka, 2004), hlm. 123

30 Undang-Undang Republik Indonesia Nomor 20 Tahun 2003 Tentang Sistim Pendidikan Nasional (Semarang: Aneka Ilmu, 2003), hlm. 12.

${ }^{31}$ Haidar Putra Daulay, Pendidikan Islam dalam Sistim Pendidikan Nasional di Indonesia (Jakarta: Kencana, 2004), h. 63, lihat juga Undang-Undang Republik Indonesia Nomor 20 Tahun 2003, hlm. 12.

32 Undang-Undang Republik Indonesia Nomor 20 Tahun 2003, hlm. 12.
} 
Berdasarkan uraian tersebut lembaga pendidikan Islam di Indonesia adalah madrasah dan pesantren.

Madrasah/pesantren adalah suatu bentuk budaya masyarakat. Sebagai sebuah komunitas, madrasah/pesantren juga memiliki budaya tersendiri. Dalam konteks ini, budaya madrasah/pesantren dipahami dalam perspektif budaya organisasi. Dipahami bahwa, budaya mengacu kepada nilai, sistem kepercayaan, norma, dan cara berpikir yang menjadi karakteristik orang-orang dalam suatu organisasi" ${ }^{33}$

Pendapat lain dikemukakan oleh Beach dan Reinhartz, budaya organisasi adalah pengertian bersama tentang lingkungan sosial organisasi dengan membagi nilai-nilai secara luas dan asumsi yang menciptakan pola perilaku tertentu dalam organisasi" ${ }^{34}$

Jadi budaya organisasi adalah suatu pola perilaku kelompok yang berupa nilai, keyakinan dan kebiasaan dalam satu organisasi. Di sini dipahami bahwa budaya organisasi merupakan konsep yang ditransformasikan dari kehidupan bersama dan kemudian dipahami sebagai pola berpikir dan bertindak untuk memberikan arah kepada pengalaman dan menyatakan bagaimana pengalaman itu terlihat, dinilai dan dilaksanakan sehingga membantu orang lain memahami kerumitan dan kekuatan kerjasama kelompok dalam organisasi.

Konsep budaya madrasah/pesantren yang dikembangkan oleh kepala madrasah/ pesantren dan unsur pimpinan lainnya merupakan inti perilaku manajerial. Budaya madrasah/pesantren memberikan warga madrasah/pesantren kerangka kerja yang luas untuk memahami problema kerja yang sukar dan hubungan yang kompleks di madrasah/ pesantren. Kepala madrasah/pesantren perlu memahami budaya madrasah/pesantren secara mendalam agar pimpinan dapat menjadi lebih baik dalam menggunakan dan memelihara nilai-nilai, keyakinan dan sikap yang penting untuk memajukan stabilitas dan pemeliharaan lingkungan pembelajaran.

Adalah sukar menetapkan suatu definisi yang konsisten berkaitan dengan budaya madrasah/pesantren (school culture). Terminologi yang telah digunakan secara bersamaan dengan beragam konsep, mencakup: iklim, etos dan hikayat. Konsep tentang budaya muncul dalam dunia pendidikan yang berasal dari tempat kerja di perusahaan, yang dimaksudkan bahwa budaya madrasah/pesantren akan memberikan arah bagi lebih efisien dan stabilnya lingkungan pembelajaran.

Kemudian budaya mencakup "pola nilai yang mendalam", keyakinan dan tradisi yang sudah terbentuk lebih sekedar pelajaran sejarah (madrasah/pesantren). Budaya madrasah/pesantren terdiri dari dalam "kepercayaan secara umum dipegangi para guru, pelajar dan kepala madrasah/pesantren". Definisi ini berada pada spektrum dunia pendidikan untuk menciptakan efisiensi lingkungan pembelajaran. Fokus aktivitas warga

${ }^{33}$ Robert G. Owens, Organizational Behavior in Education. Boston: Allyn and Bacon. 1995, hlm.79.

${ }^{34}$ Don M .Beach dan Judy Reinhatz, Supervisory Leadership. London: Allyn and Bacon, 2000, hlm.60. 
madrasah/pesantren lebih atas pentingnya nilai murni untuk mengajar dan mempengaruhi jiwa generasi muda. Edgar Schein, menjelaskan bahwa budaya organisasi mencakup aspek: (1) bentuk solusi terhadap problem internal dan eksternal yang bekerja secara konsisten bagi kelompok dan diberikan kepada anggota baru sebagai cara yang benar untuk diterima, dipikirkan, dan dirasakan dalam hubungan dengan masalah yang dihadapi, (2) asumsi yang nyata tentang sifat realita organisasi, kebenaran, waktu, ruang, sifat manusia dan hubungan manusia, (3) asumsi terhadap kebenaran yang diyakini bersama". ${ }^{35}$

Beach dan Reinhartz, ${ }^{36}$ berpendapat bahwa budaya madrasah/pesantren adalah kekuatan yang menyebabkan format pelayanan masa lalu dan membantu memelihara dan membentuk visi kolektif masa depan dari pengajaran dan pembelajaran yang seharusnya. Budaya madrasah/pesantren mengarahkan keputusan akhir yang membantu memahami madrasah/pesantren".

Budaya madrasah/pesantren dapat didefinisikan sebagai secara historis dari yang diwariskan pola makna yang mencakup norma, nilai, kepercayaan, upacara, ritual, tradisi dan pengertian mistis dalam berbagai tingkatan oleh anggota masyarakat madrasah/ pesantren. Sistem makna ini sering dipelihara yang menjadi pikiran orang dan bagaimana melakukannya.

Dapat dikatakan bahwa banyak penemuan para peneliti yang telah menekankan bukti atas budaya madrasah/pesantren. Kekayaaan dan suara budaya madrasah/pesantren berhubungan secara kuat dengan peningkatan prestasi pelajar, motivasi dan produktivitas serta kepuasan guru. Pengaruh kultur madrasah/pesantren dalam lima dimensi, yaitu: tantangan akademik, perbandingan prestasi, masyarakat madrasah/pesantren, kesadaran prestasi, persepsi tujuan madrasah/pesantren. Bagaimanapun warga madrasah/pesantren memperoleh dukungan dalam proposisi yang pelajar lebih termotivasi untuk belajar dalam madrasah/pesantren yang kulturnya kuat.

Budaya madrasah/pesantren juga berhubungan dengan sikap guru terhadap pekerjaan mereka. Dalam suatu penelitian yang berbentuk efektivitas dan ketidakefektifan budaya organisasi bahwa budaya madrasah/pesantren yang kuat telah memotivasi guru. Dalam suatu lingkungan ada ideologi organisasi yang kuat, membagi partisipasi, kepemimpinan kharismatik, dan keintiman, kepuasan kerja guru menjadi tinggi dan meningkat produktivitasnya.

Dengan demikian setiap madrasah/pesantren memiliki sebuah budaya madrasah/ pesantren, sebagian ada yang budayanya kuat atau berfungsi baik dan sebagian ada yang budayanya lemah dan kurang berfungsi. Jadi madrasah/pesantren efektif memiliki budaya yang kuat dan berfungsi mendukung visi keunggulan. Visi yang digerakkan oleh pimpinan madrasah/pesantren dalam kerjasama dengan para guru membangun nilai dan tradisi bagi

${ }^{35}$ Robert G.Owens, Organizational Behavior in Education, hlm.83.

${ }^{36}$ Beacah dan Reinhartz. Supervisory Leadership, hlm.62. 
penataan madrasah/pesantren. Karena nilai dan tradisi madrasah/pesantren membantu penyuaraan sempurna keselurhan masyarakat madrasah/pesantren.

Adapun budaya organisasi yang perlu dikembangkan bagi kemajuan lembaga pendidikan Islam adalah sebagai berikut:

1. Membangun Tim Kerja di Madrasah/Pesantren

Tim kerja dapat menangani pemecahan masalah dan pembuatan keputusan di madrasah/pesantren dan pada Dinas Pendidikan Kabupaten/Kota atau Cabang Dinas Pendidikan Kecamatan. Keberadaan Tim Kerja adalah untuk membangun hubungan lebih kuat di antara yang terlibat dalam aktivitas manajemen sekolah. Pembentukan tim kerja ini pada akhirnya dapat menguntungkan para pelajar, sebab semakin lebih banyak orang yang menggunakan perspektif lebih luas untuk menolong mensukseskan program unggulan sekolah yang diharpkan bersama.

Menurut Lewis, $\mathrm{Jr},{ }^{37}$ bahwa mengubah perilaku (motivasi) harus dilaksanakan melalui medium tim kerja dari pada melalui usaha individu. Hal ini menjadi tanggung jawab kepala madrasah/pesantren dan pengawas untuk mempengaruhi perilaku anggota melalui usaha tim kerja yang aktif".

Untuk itu, tim kerja merupakan bahagian penting dalam menangani perubahan yang diinginkan di sekolah. Selain proses pemberdayaan personil, sekaligus membentuk budaya sekolah yang baik bagi peningkatan kualitas sekolah sesuai harapan masyarakat.

Pembentukan tim kerja dalam pendekatan kepemimpinan di sekolah adalah dalam rangka mengembangkan kemampuan personil dan rasa tanggung jawab dalam sekolah. Menurut Overton, ${ }^{38}$ hal yang perlu dipertimbangkan dalam kepemimpinan tim kerja, yaitu : (a) keadilan, (2) ketenangan, (3) sikap positif, (4) mau mendengarkan, (5) kesabaran, (6) pengetahuan".

Sebuah tim kerja di sekolah harus memiliki berbagai keterampilan yang memungkinkan saling mengisi dan melengkapi untuk mewujudkan program unggulan yang diinginkan sebagai realisasi dari mengejar kualitas. Dijelaskan oleh Nanus dan Dobbs, bahwa :" A strong team in a nonprofit organization is one in which team members have diverse skills and backgrounds but share common goals, are commotted to a common cause, provide mutual support and communicate well which one other. ${ }^{39}$ Keberadaan tim yang diinginkan adalah tim yang kuat dengan keterampilan berbeda antara anggota tim, tujuan yang ingin dicapai terbagi kepada semua anggota, serta memiliki komitmen hlm.177.

37James Lewis, Jr. Scool Management By Objectives.(New York: Parker Publishing Company, Inc. 1974),

${ }^{38}$ Rodney Overton..Leadership Made Simple.(Singapura: Wharton Books, Pte.Ltd.. 2002), hlm.90.

39 Burt Nanus and Stephen M. Dobs. Leaders Who Make A Difference (San Francisco: Jossey Bass Publishers. 1999), hlm.148. 
dalam memperjuangkan tujuan melalui komunikasi yang antara sesama anggota tim dalam suatu kepemimpinan.

Tim kerja memiliki beberapa pengaruh positif. Pertama; semakin banyak orang terlibat dalam pengambilan keputusan, akan semakin baik dalam melakukan keputusan tersebut. Kedua; anggota tim secara terus menerus belajar dari orang lain dalam timnya yang memiliki gagasan cemerlang dan segar. Ketiga; lebih banyak dan baik informasi serta tindakan yang berasal dari kelompok orang dengan keragaman sumberdaya dan keterampilan. Keempat; adalah baik kesempatan bahwa kesalahan-kesalahan dapat diatasi dan diperbaiki. Kelima; risiko yang ada ditangani secara bersama karena dari kekuatan bersama kelompok. Sesuatu yang dirasa akan terjadi, bahwa organisasi dapat lebih berharap semua pelaku mungkin dalam organisasi yang sama, karena ada kegembiraan dan pengertian, Keenam: tim merupakan cara yang sangat efektif dalam meningkatkan produktivitas dan moral.

2. Melaksanakan fungsi-fungsi manajemen secara konsisten.

Organisasi yang baik, akan melakukan kegiatan manajemen yang diawali dari perencanaan dan diakhiri dengan evaluasi yang dilakukan secara konsisten dan tuntas. Kegiatan yang berulang mengakibatkan menjadi budaya bagi organisasi lembaga madrasah/pesantren itu sendiri. Kebanyakan kegiatan ini dilakukan secara ketat diawal perjalanan lembaga pendidikan dan kendur ditengah bahkan diakhir. Dengan masuknya kegiatan ini menjadi budaya organisasi lembaga madrasah/pesantren, diharapkan regenerasi pimpinan, pendidik dan tenaga kependidikan akan meneruskan tradisi ini.

3. Melaksanakan peraturan dan tata tertib Madrasah/Pesantren dengan rasa tanggung jawab.

Peraturan yang ditegakkan untuk semua lapisan bagi pimpinan, pendidik, tenaga kependidikan serta siswa/santri, perlu menjadi budaya bagi lembaga. Namun penegakan disiplin harus dilaksanakan secara arif dan bijaksana, karena penegakan disiplin terhadap peraturan yang dilakukan secara kaku dapat menjadi bumerang bagi lembaga itu sendiri. Intinya penegakan disiplin diadakan untuk teraturnya kegiatan pendidikan yang dilakukan.

Menurut penelitian Lislie J. Fyans, Jr dan Martin L. Maehr dalam Asri Laksmi Riani bahwa ada lima dimensi budaya organisasi di sekolah/madrasah/pesantren yang perlu dikembangkan yaitu: 1). Tantangan Akademik, 2). Prestasi komparatif, 3). Penghargaan terhadap prestasi, 4). Komunitas sekolah/madrasah/pesantren, 5). Persepsi tentang tujuan sekolah/madrasah/pesantren ${ }^{40}$.

${ }^{40}$ Asri Laksmi Riani, Budaya Organisasi ( Graha Ilmu: Yogyakarta, 2011 ), hlm. 124 
Bila beberapa komponen di atas dilakukan secara konsisten maka budaya organisasi di madrasah/pesantren cenderung menjadi kuat. Budaya organisasi bertindak sebagai perekat sosial yang mengikat sesama anggota organisasi bersama-sama dalam satu visi dan tujuan yang sama.

\section{PENUTUP}

Lembaga pendidikan merupakan suatu organisasi, dan budaya yang ada di tingkat lembaga pendidikan merupakan budaya organisasi. Resep utama budaya organisasi adalah interpretasi kolektif yang dilakukan anggota-anggota organisasi berikut hasil aktivitasnya.

Budaya organisasi dapat dikatakan baik jika mampu menggerakkan seluruh personal secara sadar dan mampu memberikan kontribusi terhadap keefektifan serta produktivitas kerja yang optimal. Dengan demikian budaya organisasi madrasah/pesantren sebagai bagian kebiasaan dalam suatu organisasi yang saling berinteraksi dengan struktur formulanya untuk menciptakan norma perilaku pelaku organisasi dan menentukan arah organisasi secara keseluruhan dalam rangka mencapai tujuan organisasi madrasah/pesantren. 


\section{DAFTAR PUSTAKA}

Al-Qur'anul Karim

Anwar Prabu Mangkunegara, Perilaku dan Budaya Organisasi, Bandung: Refika Aditama, 2005.

Azra Azrumardi. Pendidikan Islam Tradisi dan Modernitas Menuju Milenium Baru, Jakarta : Logos.1999

Al-Buthy Muhammad Sai'd Ramadhan, Fiqhus Sirah:Dirasat Manhajiah 'Ilmiyah li SiratilMusthafa 'alaihish-Shalatu was-Salam. terj. Aunur Rafiq Shaleh Tamhid. Cet. Ke-10, Jakarta: Rabbani Press, 2006

Anshari, Endang Saifuddin, Pokok-Pokok Pikiran Tentang Islam. Cet. Ke-1, Bandung: Pelajar, 1969

Bahtiar Effendy dan Fahry Ali, Merambah Jalan Baru, Rekontruksi Pemikiran Indonesia Masa Orde baru, Bandung : Mizan, 1990.

Bratakusumah, "Kajian Manajemen Stratejik", Modul Pendidikan danPelatihan Kepemimpinan Tingkat II, Buku 2, Pusat Pendidikan dan Latihan SPIMNAS Bidang Kepemimpinan, Jakarta: Lembaga Administrasi Negara, 2002

Cartwright Jeff, Cultural Transformation, London: Pearson Education Limited, 1999.

Deddy Mulyadi \& Veithzal Rivai, Kepemimpinan dan Perilaku Organisasi, Ed. III, Jakarta: Rajagrafindo Persada, 2009.

Daulay Haidar Putra, Sejarah Pertumbuhan dan Pembaharuan Pendidikan Islam di Indonesia, Jakarta: Kencana Pranada Media, 2007. Dinamika Pendidikan Islam, Bandung : Citapustaka, 2004.

, Sejarah Pertumbuhan Dan Pembaharuan Pendidikan Islam di Indonesia, Bandung : Cita Pustaka Media, 2001. Pendidikan Islam, Dalam Sistem Pendidikan Nasional, Jakarta : Prenada Media, 2004.

Faisal Ismail, Paradigma Kebudayaan Islam: Studi Kritis dan Refleksi Historis. Cet. Ke-2, Yogyakarta: Titian Ilahi Press, 1997

Hasan Asari, Menikap zaman Keemasan Islam, Bandung : Cita Pustaka Media, 2007.

John Newstrom dan Davis, Human Behavior at Work: Organizational Behavior, New York: McGraw Hill International, 1989.

John M. Ivancevich James L. Gibson, dan James H. Donnelly, Jr, Organizations, Boston: McGraw-Hill Higher Education, 2000. 
Judy Reinhatz dan Don M .Beach, Supervisory Leadership, London: Allyn and Bacon, 2000.

Keputusan Menteri Pendayagunaan Aparatur Negara RI Nomor 25/KEP/M.PAN/04/2002 tentang: Pedoman Pengembangan Budaya Kerja Aparatur Negara, Jakarta: 2002.

Keith D, dan J.W. Newstorm, Organization Behavior: Human Behaviorat Work. ed. 9, McGrawHill, Inc. 1993.

Kinicki Angelo dan Kreitner Robert, Organizational Behavior, New York: McGraw-Hill Higher Education, 2001.

Kamus Munjid fi al - luhgah wa al - I'lam, Beirut : Maktabah Syarqiyyah,1986.

Lexy J. Maloeng, Metodologi Penelitian Kualitatif. Cet. Ke-27, Bandung: Remaja Rosdakarya, 2010.

Lundberg Craig C., dalam Peter J. Frost et. al, Organization Culture, California: Sage Publication, 1985.

Denys Lombard, Nusa Jawa: Silang Budaya Kajian Sejarah Terpadu Bagian II: Jaringan Asia. Cet. Ke-4, Jakarta: Gramedia, 2008.

Koentjaraningrat, Kebudayaan, Mentalitet dan Pembangunan, Cet. Ke-1, Jakarta: Gramedia, 1976

M. Pabundu Tikam, Budaya Organisasi dan Peningkatan Kinerja Perusahaan, Jakarta: Bumi Aksara, 2006.

M. A. West, Mengembangkan Kreativitas Dalam Organisasi, ed. 1, Yogjakarta: Kanisius, 2000.

Mukhtar \& Iskandar, Orientasi Baru Supervisi Pendidikan, Jakarta: Gaung Persada, 2009.

Moeljono Djoko Santoso, Culture-Budaya Organisasi dalam Tantangan, Jakarta: Elex Media Komputindo, 2005.

Miles, Matthew B dan A. Michael Huberman, Analisis Data Kualitatif: Buku Sumber tentang Metode-Metode Baru, terj. Tjejep Rohendi Rohidi, Jakarta: UI Press, 1992

Plastrik Peter dan D. Osborn, , Memangkas Birokrasi, ed. Revisi, Jakarta: PPM, 2000

Phegan, Barry, Developing Your Company Culture, Berkeley:Contex Press, Meridian Group, Inc., 2000.

Peursen Van C.A, Startegi Kebudayaan,terj. Dick Hartoko. Cet. Ke-1 Yogyakarta: Yayasan Kanisius, 1976

Poerbakawatja Soegarda, Ensiklopedi Pendidikan, Jakarta: Gunung Agung, 1976.

Robert A. Baron dan Jerald Greenberg, Behavior in Organizations, New Jersey: Prentice-Hall, 2003. 
FITRAH Vol. 01 No. 2 Juli-Desember 2015

Robbins Stephen P., Organizational Behavior, New Jersey: Prentice Hall International, Inc., 2003.

Robert G. Owens, Organizational Behavior in Education, Boston: Allyn and Bacon. 1995.

Soekanto Soerjono, Sosiologi suatu Pengantar, Jakarta : Grafindo, 2003. Sofo F, Pengembangan Sumber Daya Manusia, ed. 1, Surabaya: Airlangga University Press. 2003.

Schein Edgar H, Organizational Culture and Leadership, San Francisco : Jossey-Bass, 1997.

An Organizational Culture and Leadership, San Fransisco: Yossey Bass Publisher, 1992.

Sukmadinata Nana Syaodih, dkk, Pengendalian Mutu Pendidikan Sekolah Menengah (Konsep, Prinsip dan Instrumen). Aditama.

Sutrisno Edy, Budaya Organisasi, Jakarta: Kencana Prenada Media Group, 2010.

Sugiyono, Metode Penelitian Pendidikan; Pendekatan Kuantitatif, Kualitatif, dan RED. Cet. Ke-2, Bandung: Alfabeta, 2006.

Triguno, Budaya Kerja: Menciptakan Lingkungan yang Kondusif Untuk Meningkatkan Produktivitas Kerja, ed. 6, Jakarta: Golden Terayon Press, 2004.

Tan Victor S.L, Changing Your Corporate Culture, Singapore: Times Books International, 2002.

Turmudi Endang. Perselingkuhan Kyai dan kekuasaan, Yogyakarta: LkiS. 2003.

Tilaar H.A.R, Multikulturalisme : Tantangan-Tantangan Global Masa Depan dalam Transformasi Pendidikan Nasional, Jakarta: Grasindo, 2004.

Vecchio Robert P., Organizational Behavior, Orlando: Harcourt Brace \& Company, 1995.

Verkuyl, J. Etika Kristen dan Kebudayaan, terj. Soegiarto. Cet. Ke-2, Jakarta: Badan Penerbit Kristen 1966.

Wibowo, Budaya Organisasi, Jakarta: Rajagrafindo Persada, 2010.

Want Jerome, Corporate Culture, New York: St. Martin's Press, 2007.

Zwell, Michael, Creating a Culture of Competence, New York: John Wiley \& Sons, Inc., 2000. 